\title{
Infective Endocarditis
}

National Cancer Institute

\section{Source}

National Cancer Institute. Infective Endocarditis. NCI Thesaurus. Code C78265.

An infectious process involving the endocardial layer of the heart. 